DOI: https://doi.org/10.32839/2304-5809/2019-5-69-31

УДК 75.017 .4

Малежик Ю.М., Балах Д.І.

Центральноукраїнський державний педагогічний університет імені Володимира Винниченка

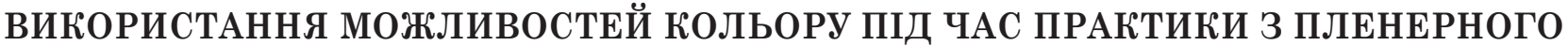 ЖИВОПИСУ У МАЙБУТНІХ УЧИТЕЛІВ ОБРАЗОТВОРЧОГО МИСТЕЦТВА
}

Анотація. У статті висвітлено проблему кольору та його властивостей у процесі підготовки майбутніх учителів образотворчого мистецтва з пленерного живопису. В процесі наукового дослідження з'ясовано, що вирішення сучасних художніх завдань відбувається через вивчення предметів, об'єктів навколишнього середовища, розуміння їх кольору і спостереження за їх відображенням у витворах образотворчого мистецтва під час практики з пленерного живопису у майбутніх вчителів образотворчого мистецтва, зокрема. Авторами встановлено, що активізащія образотворчої діяльності художника, який працюе на пленері, здійснюеться шляхом отримання знань про природу кольору і пізнання законів колористики, що важливо для правильної реалістичної побудови в живописі. Робота на відкритому повітрі, в оточенні природних об'єктів, активізує формування творчої самостійності студентів, прискорюе формування необхідних вмінь та навичок майбутніх вчителів образотворчого мистецтва. Поглиблене вивчення змісту пленерної практики посилюе якість підготовки молодих педагогів-митців, допомагає сформувати їхній світогляд, естетичні смаки, підвищуе педагогічну та художню майстерність.

Ключові слова: колір, колорит, простір, етюд, пленер, живопис, майбутній учитель образотворчого мистецтва.

Malezhyk Yuliia, Balakh Daryna

Volodymyr Vinnychenko Central Ukrainian Pedagogical University

\section{THE USE OF COLOUR OPPORTUNITIES DURING THE OPEN-AIR PAINTING PRACTICE BY FUTURE FINE ARTS TEACHERS}

Summary. In the article the problem of color and its properties in the process of preparation of future teachers of fine arts from plener painting is highlighted. The problem of colour and its properties and values in theprocess of open-air painting is dealt with the article. It is generally known that there is nothing colourless in nature: some colours are very bright and clear, others are pale and so unclear that it's sometimes difficult even to give a name to them. However, the concept of colour and its perception are very complicated. Applying the colour properties creates specific colouring influenced by the artist's feelings and mood. The set of impressions, harmonious combination of colours brought together in the painting creates a unique colouring of the pieces of fine arts. In the scientific research process, it was learned that the solution to contemporary artistic problems occurs through the study of objects, environment, understanding their colour and observation of their reflection in works of fine art during the open-air painting practice by future fine arts teachers, in particular. It was found, that the revitalization of the visual activity of the artist who works on the open-air practice occurs through the gaining knowledge about the nature of colour and cognition of colouring laws, which is important for the correct realistic painting construction. Skills are masterfully sharpened by artists on out-of-town practices, in real space, and sketches become independent works or a sub-painting for a work that will be completed in the workshop. It is the open-air work, surrounded by natural objects, activates the formation of students', creative autonomy, accelerates the formation of the necessary skills and abilities of future fine arts teachers. That's why we can say that open-air painting practice allows future fine arts teachers to establish the link between the world of nature and human, to increase knowledge about the environment, to develop creative and cognitive activities, express their thoughts on paper by means of colour and colour decision, to build on painting skills. In-depth research on the open-air practice content enhances the quality of the young educators-artists training, helps to shape the worldview, aesthetic tastes increases pedagogical and artistic skills.

Keywords: a colour, space, a study, an open-air painting practice, a painting, a future teacher of fine arts.

$\Pi$ остановка проблеми. Протягом століть колір відігравав істотну роль у мистецтві i був одним із найпотужніших художніх інструментів. Усе, що нас оточуе і що ми бачимо, має колір, впливає на настрій завдяки кольору. Майбутньому художнику важливо знати і вміти правильно використовувати символіку кольору в сучасному середовищі, гармонізувати кольорові відношення в навколишньому просторі. Підготовка майбутніх учителів образотворчого мистецтва під час проходження художньо-творчої практики з пленеру, надає можливість практично використати набуті знання під час теоретичного навчання.

Аналіз останніх досліджень і публікацій. Для повноти розуміння теми й аналіз останніх досліджень, опрацьовано роботи сучасних нау- ковців з пленерного живопису та його компонентів для кращої підготовки майбутнього педагогахудожника (B.M. Давидов) [11], кольору та його сприйняття (Л.І. Сотник) [10], проаналізовано художню літературу (Ф. Серрано) та інших.

Зокрема, проблему підготовки майбутніх учителів образотворчого мистецтва на пленері у своїх роботах досліджували: О. Музика [3], В. Черватюк [5], I. Чмелик [6]. Щодо праць з живописної грамоти було розглянуто роботи В.В. Визера [1], А.С. Зайцева [2], Ю.П. Шашкова [7], А.А. Унковського [4].

Виділення не вирішених раніше частин загальної проблеми. Отже, поглиблення і розширення уявлень про колір як засіб художнього вираження; вдосконалення практичних умінь і навичок використання виражальних можливос- 
тей кольору; освоєння способів досягнення колірної гармонії і прийомів колористичного рішення композиції; формування усвідомлення того, що культура сприйняття кольору - невід'ємна складова загальної і професійної культури людини. Однак, тема кольоросприйняття та використання саме можливостей кольору під час практики на пленері для вчителів образотворчого мистецтва, на нашу думку, є недостатньо розкритою.

Метою роботи $є$ дослідження властивостей кольору та його можливостей під час пленерної практики у майбутніх учителів образотворчого мистецтва.

Виклад основного матеріалу. Живопис, як вид образотворчого мистецтва зародився дуже давно. Особливості створення живописних робіт, полягають у створенні полотен художніми матеріалами, які найбільш відображають дійсність. Головний виразний засіб живопису е колір, його здатність викликати різні почуття, асоціації, посилювати емоційність зображення.

Пленерний живопис - це живопис, створений на відкритій території, задачею якого $є$ передати барвисте багатство природи, світло та простір. Найчастіше зображують пейзажі, але художники не нехтують й іншими жанрами живопису (портретом, сюжетно-тематичними, мініатюрами та іншими) - це фрігури людей, тварини, архітектура зображені в природному повітряному середовищі [7].

Метою пленеру є:

- удосконалення профресійних навичок цілісного сприйняття;

- відтворення в живописі кольорових співвідношень основних компонентів природи (небо, земля, вода);

- навчитися у природне середовище розміщувати архітектурні споруди та фрігури людей;

- розширення розуміння в умовах реального природного середовища понять кольорового тону, світла, насиченості, колориту, кольорового масштабу та ін.;

- розвинути творчу уяву - створювати засобами живопису узагальнені етюди з натури і художні образи в ескізах;

- формування глибокої просторової орієнтації профресійно сприймати натуру в природному тримірному просторі.

В процесі виконання етюдів розвиваються такі навички:

- навик аконстантності сприйняття форми і кольору;

- навик передачі тонально-колірних співвідношень в межах колірної гами;

- звичка контролю контрастів;

- навик запам'ятовування та відтворення колірного образу;

- навик володіння образотворчими і композиційними засобами;

- навик оволодіння технікою живопису.

Для реалізації цих навиків художники послуговуються такими методами роботи 3 орарбами як: метод роботи з аквареллю, гуашшю, олійними фрарбами. Наразі ж знаходять для себе й інші нові матеріали, техніки. Так наприклад, пастель, акрил та інші матеріали, поступово входять до пленерного живопису [1, с. 56].

Виконання навчальних етюдів на пленері суттево відрізняеться від роботи у приміщенні: пред- мети натюрморту або інтер'єр весь час залишаються нерухомими, освітлення та світло-повітряне середовище відносно постійні, зображений простір неглибокий, добре видні фрорма, пропорції, колір, матеріальність предметів, окремі деталі. У жанрах натюрморту та інтер'єру увага та живописне зацікавлення художника в основному зосереджено на характері форми, матеріалі предметів, колірно-тональному моделюванні, цілісному взаємозв 'язку предметів. На пленері абсолютно нові, незвичні умови - активне світлове середовище, де локальний колір збагачений масою живих та рухомих рефлексів. Різноманітні стани освітлення створюють надзвичайно багаті можливості вивчення колірних відношень у природі [9].

Протягом століть колір відігравав істотну роль у мистецтві і був одним із найпотужніших художніх інструментів. Художнику важливо знати і вміти правильно використовувати символіку кольору в сучасному середовищі, гармонізувати кольорові відношення в навколишньому просторі

Як зазначалося вище, колір - $є$ однією з основних ознак будь-якого предмета, до того ж дуже мінливою. Той самий за кольором предмет може сприйматись нашим зором по-різному, залежно від його положення у просторі, освітлення тощо. Справжній колір предмета залежно від його просторово положення (віддалення), сили та якості освітлення, навколишнього середовища змінюється за ясністю, кольоровим тоном, насиченістю. У свою чергу зміна тону, якості і насиченості тону предметів залежить від кількості і величини частинок вологи й пилу в повітрі, які утруднюють проходження кольорових променів і впливають на зміну кольору. Ці основні властивості кольору невід'ємно присутні у пленерній практищі художників [7].

Під час пленерної практики, можна спостерігати за ефектами повітряної перспективи на повну силу, в залежності як предмети розташовані відносно художника, це є основним завданням митця в етюді. При цьому декоративний підмальовок сприяе узагальненню кольорів, появи тонкого колориту, який в буквальному сенсі не передається при «списуванні» кольору з натури в майстернях [5, с. 34].

Майбутньому вчителеві образотворчого мистецтва, знання 3 кольорознавства допомагають професійно підходити до створення колірного ладу пейзажного етюду. Колірна гама в живописі будуеться за трьома принципами:

- за принципом контрастного зіткнення кольорів які лежать напроти один одного на кольоровому спектрі; контраст викликає напругу, чіткість, різкість, гармонія - лагідність, спокій, мелодію тонів;

- принцип кольорової гармонії - м'яке зближення кольорів, які лежать близько одна до одної на кольоровому спектрі;

- змішаний принцип поєднання кольорів.

Навчальна практика «Пленер» дає змогу простежити різноманіття кольорів у природі. Спочатку студенту педагогу-художнику важко бачити кольори предметів і об'єктів, змінені відстанню, силою і кольором освітлення. Необхідно пам'ятати, що колірна єдність пейзажу багато в чому створюеться за рахунок кольору освітлення. Ранком у натурі переважають золотаво-рожеві відтінки, увечері - жовто-жовтогарячі, у похмурий 
день - сіро-сріблисті, при світлі місяця - блакитні і зеленуваті кольори. Усі часи року мають свої характерні кольори в пейзажі [10, с. 33].

Живописне зображення пейзажу створюеться на основі знань законів лінійної, повітряної і колірної перспективи, треба пам'ятати і про цілісність бачення і метод роботи відношеннями. У перших етюдах необхідно навчитися передавати основні колірні розходження між об'єктами пейзажу: силуетами дерев, загальною площиною землі, хмарами, гладдю води і т.д.

Успіх починаючого живописця багато в чому залежить від уміння бачити в натурі і знаходити на етюді відносини великих колірних плям. Працюючи над пейзажем, неможливо його просто «змалювати». Пейзаж вимагатиме від художника схвильованого, поетичного відношення до дійсності.

Пленерна практика студентів-художників та їхній теоретичний досвід дають можливість стверджувати, що процес створення колірного стану етюду можна умовно розподілити на два головних етапи:

- виявлення головного колірного відношення теплохолодності у натурі;

- знаходження групи фрарб, що складають головні відношення етюду.

Визначати колірні відношення потрібно від загального колірного стану середовища та обумовленого кольору предметів до їх локального кольору. Якщо робота ведеться від кольору предмету до загального стану, можливо перебільшення значення предметного кольору та викривлення відношень в етюді [8].

Колір - явище постійно змінне, в природі залежить від погоди, часу доби, пори року, вологості повітря, тому для пленерної роботи $є$ надважливим завданням точна i швидка робота у кольорі, передача настроїв і навколишніх деталей, які трансформуються у твір мистецтва за відчуття колориту. Адже саме вдале поєднання кольорів у процесі створення пленерного етюду, надає можливість чітко й емоційно передати власні враження від короткочасного сприйняття побаченого сюжету. Таким чином, за допомогою колориту майбутній учитель образотворчого мистецтва, має змогу передати головну ідею карти- ни, викликати певний настрій, власні емоції при написанні живописних етюдів.

Висновки. Отже, узагальнюючи вищевикладене, слід зазначити, що пленерна практика сприяе кращому засвоєнню умінь та навичок в процесі підготовки майбутнього вчителя образотворчого мистецтва, а за допомогою властивостей кольору, допомагає відчути колірні особливості визначеного стану природи, їі пластичні характеристики і передати це в колористичній єдності короткочасних або довготривалих етюдів.

Проведене дослідження дає можливість стверджувати, що колір створюе цілісні уявлення про матеріальні якості предметів і явищ навколишнього світу та враження про їх забарвлення і психофізичний стан. За допомогою виражальних можливостей кольору можна передати фрактуру будь-якого зображуваного об’екту: шовку, атласу, дерева, хутра, мережива, кришталю і т.д.

Досліджуючи основні властивості кольору, ми дійшли висновку, що характеризуючи кольоровий тон, насиченість і ясність, можна правильно визначити колір будь-якого предмета, якість кольору, його зв'язок $з$ іншими кольорами.

Було узагальнено виражальні можливості кольору такими засобами, як поєднання відтінків згідно з правилами колірного спектру, свідомий поділ кольорів на хроматичні та ахроматичні, дотримання законів світлотіні, дотримання на полотні головного колірного тону.

В процесі наукового дослідження було встановлено, що опанування властивостей кольору, його виражальних можливостей активізуеться у процесі роботи на «відкритому повітрі», тобто пленері. Поглиблене вивчення виражальних можливостей кольору під час пленерної практики посилює якість підготовки молодих педагогів-митців, допомагає формувати їхній світогляд, естетичні смаки, підвищує педагогічну та художню майстерність.

Наше дослідження свідчить, що пленерна практика для майбутніх учителів образотворчого мистецтва, це площина не тільки для початку самостійної творчої роботи, але і можливість вдосконалювати вміння та навички в образотворчому мистецтві, оволодівати новими техніками, експериментувати з кольором у просторі.

\section{Список літератури:}

1. Визер В.В. Живописная грамота. Основы пейзажа. Спб. : Питер, 2007. 192 с.

2. Зайцев А.С. Наука о цвете и живопись. Москва : Искусство, 1986. 158 с.

3. Музика О. Пленерна практика як важливий компонент підготовки майбутнього вчителя образотворчого мистецтва. Проблели підготовки сучасного вчителя. 2012. № 6(2). С. 47-52.

4. Унковский А.А. Живопись. Вопросы колорита. Москва : Просвещение, 1980. 280 с.

5. Черватюк В. Пленерний живопис - невід'ємна складова художньої освіти. Актуальні проблели мистецької практики і мистеитвознавчої науки. 2010. Вип. 3. С. 403-409.

6. Чмелик I. Пленерна практика у Карпатах як важливий чинник професійної підготовки вчителя мистецьких дисциплін. Гірська школа Українських Kарпат. 2013. № 10. С. 166-168.

7. Шашков Ю.П. Живопись и ее средства. Москва : Трикста, Академический проект, 2006. 144 с.

8. Юр М. Естетико-культурологічні особливості художнього простору в живописі імпресіонізму / MICT: Muстецтво, історія, сучасність, теорія. 2014. Вип. 10. С. 255-269. URL: http://nbuv.gov.ua/UJRN/ Mist_2014_10_21 (дата звернення: 21.05.2019).

9. Сутність та основні властивості кольору. Нова педагогіка. URL: http://www.novapedahohika.com/noloms-650-1.html (дата звернення: 21.05.2019).

10. Сотник Л.І. Колір і його значення в мистецтві. Вісник ХДАМД. Харків : ХДАМД, 2015. № 6. С. $32-36$.

11. Давидов В.M. Зміст навчальної практики «пленер» у професійній підготовці педагога-художника. Наукові записки КДПУ. Серія : Педагогічні науки. 2017. Вип. 155. С. 107-111. URL: http://nbuv.gov.ua/UJRN/ Nz_p_2017_155_25 (дата звернення: 22.05.2019). 


\section{References:}

1. Vyzer V.V. (2007). Zhyvopysnaia hramota. Osnovy peizazha. Spb. : Pyter. 192 p. (in Russian)

2. Zaitsev A.S. (1986). Nauka o tsvete y zhyvopys. Moskva : Yskusstvo. 158 p. (in Russian)

3. Muzyka O. (2012). Plenerna praktyka yak vazhlyvyi komponent pidhotovky maibutnoho vchytelia obrazotvorchoho mystetstva. Problemy pidhotovky suchasnoho vchytelia. Vol. 2, № 6. Pp. 47-52.

4. Unkovskyi A.A. (1980). Zhyvopys. Voprosy koloryta. Moskva : Prosveshchenye. 280 p. (in Russian)

5. Chervatiuk V. (2010). Plenernyi zhyvopys - nevidiemna skladova khudozhnoi osvity. Aktualni problemy mystetskoi praktyky i mystetstvoznavchoi nauky. Vol. 3. Pp. 403-409. (in Ukrainian)

6. Chmelyk I. (2013). Plenerna praktyka u Karpatakh yak vazhlyvyi chynnyk profesiinoi pidhotovky vchytelia mystetskykh dystsyplin. Hirska shkola Ukrainskykh Karpat. № 10. Pp. 166-168. (in Ukrainian)

7. Shashkov Yu.P. (2006). Zhyvopys y ee sredstva. Moskva : Tryksta, Akademycheskyi proekt. 144 p. (in Russian)

8. Iur M. (2014). Estetyko-kulturolohichni osoblyvosti khudozhnoho prostoru v zhyvopysi impresionizmu [Aesthetic and cultural characteristics of the artistic space in the painting of impressionism]. Mystetstvo, istoriia, suchasnist, teoriia. Vyp. 10. Pp. 255-269. Available at: http://nbuv.gov.ua (accessed: 21.05.2019).

9. Sutnist ta osnovni vlastyvosti koloru [Essence and basic properties of color]. Nova pedahohika. Available at: http://www.novapedahohika.com/noloms-650-1.html (accessed: 21.05.2019).

10. Sotnyk L.I. (2015). Kolir i yoho znachennia v mystetstvi [Color and its significance in art]. Visnyk KhDAMD. Kharkiv : KhDAMD. № 6. Pp. 32-36. (in Ukrainian)

11. Davydov V.M. (2017). Zmist navchalnoi praktyky «plener» u profesiinii pidhotovtsi pedahoha-khudozhnyka [Contents of educational practice "plein air" in the professional training of a teacher-artist]. Naukovi zapysky KDPU. Vyp. 155. Pp. 107-111. Available at: http://nbuv.gov.ua (accessed: 22.05.2019). 